\title{
Prognosis in Malignant Tumors of the Kidney
}

\author{
Seigi Tsuchida and Hiroatsu Sugawara \\ Department of Urology (Prof. S. Shishito), \\ Tohoku University School of Medicine, Sendai
}

In an attempt to investigate the prognosis of malignant tumors of the kidney, a follow-up study was made in 29 cases of hypernephroma and 11 cases of earcinoma of the renal pelvis over a period ranging from 3 to 9 years, and the following results were obtained.

1) The 3 and 5 -year survival rates of hypernephroma treated by nephrectomy were $39 \%(9 / 23)$ and $30 \%(4 / 13)$ respectively, while those of pelvic tumor were $33 \%$ $(3 / 9)$ and $33 \%(2 / 6)$.

2) In cases of these malignant tumors the prognosis was generally poor when: a) the patients received medical examinations late after the first symptoms, b) the tumor had attained a large size already at the first examination, c) extirpated tumor was also large, d) extracapsular spread had already occurred, and e) there were demonstrable metastatic lesions.

Renal tumors are rather rare, and not a few patients are found inoperable since they are apt to come for consultation in considerably advanced stages of the disease. For these reasons, the prognosis after surgical treatments of renal neoplasms has been discussed only in a limited number of reports.

In the present paper the results of a follow-up study made on patients with hypernephroma or carcinoma of the renal pelvis for periods of 3 or 5 years are described.

\section{Materials and Results}

This paper presents the result obtained on a total of 40 adult patients with malignant renal neoplasms; hypernephroma or pelvic carcinoma. Of these there were 6 cases of hypernephroma (including 4 cases of exploratory laparotomy and 2 non-operative cases) and 2 cases of pelvic tumor (one of exploratory laparotomy and one non-operative) where the disease was found to be too advanced for nephrectomy. These non-nephrectomized patients will be discussed separately.

Results in nephrectomy cases

The survival time after discharge from the hospital in the group of 32 patients having received nephrectomy is shown in Table 1. As is apparent from the table, the 3-year survival rate for this group was $9 / 23(39 \%)$ for hypernephroma and

Received for publication, March 27, 1968. 
TABLE 1.

\begin{tabular}{|c|c|c|c|c|c|c|}
\hline & & \multirow{2}{*}{$\begin{array}{c}\text { Death } \\
\text { at } \\
\text { operation }\end{array}$} & \multicolumn{4}{|r|}{ Less } \\
\hline & & & $1 \mathrm{mo}$ & $3 \mathrm{mos}$ & $6 \mathrm{mos}$ & $1 \mathrm{yr}$ \\
\hline \multirow[t]{2}{*}{$\begin{array}{l}\text { Hyper- } \\
\text { nephroma }\end{array}$} & $\begin{array}{l}\text { Observed for } \\
\text { more than } \\
3 \text { yrs }\end{array}$ & 1 & 1 & & 5 & 2 \\
\hline & $\begin{array}{l}\text { Observed for } \\
\text { more than } \\
5 \text { yrs }\end{array}$ & 1 & 1 & & 2 & 1 \\
\hline \multirow[t]{2}{*}{$\begin{array}{l}\text { Pelvic } \\
\text { tumor }\end{array}$} & $\begin{array}{l}\text { Observed for } \\
\text { more than } \\
3 \text { yrs }\end{array}$ & & 1 & & 2 & 1 \\
\hline & $\begin{array}{l}\text { Observed for } \\
\text { more than } \\
5 \text { yrs }\end{array}$ & & 1 & & 3 & \\
\hline
\end{tabular}

Figures in parentheses indicate

TABle 2. Age of onset

\begin{tabular}{c|c|c|c|c|c|c|c|c|c}
\hline Age (yrs) & $1-10$ & $11-20$ & $21-30$ & $31-40$ & $41-50$ & $51-60$ & $61-70$ & $71-$ & Total \\
\hline $\begin{array}{c}\text { Hyper- } \\
\text { nephroma }\end{array}$ & $1(1)$ & & 1 & $3(2)$ & $5(3)$ & $8(3)$ & $4(1)$ & 1 & $23(9)$ \\
\hline Pelvic tumor & & - & 1 & & 1 & $2(2)$ & 3 & $2(1)$ & $9(3)$ \\
\hline Total & $1(1)$ & & 2 & $3(2)$ & $6(3)$ & $10(4)$ & $7(2)$ & $3(1)$ & $32(12)$
\end{tabular}

Figures in parentheses indicate the number of patients still alive.

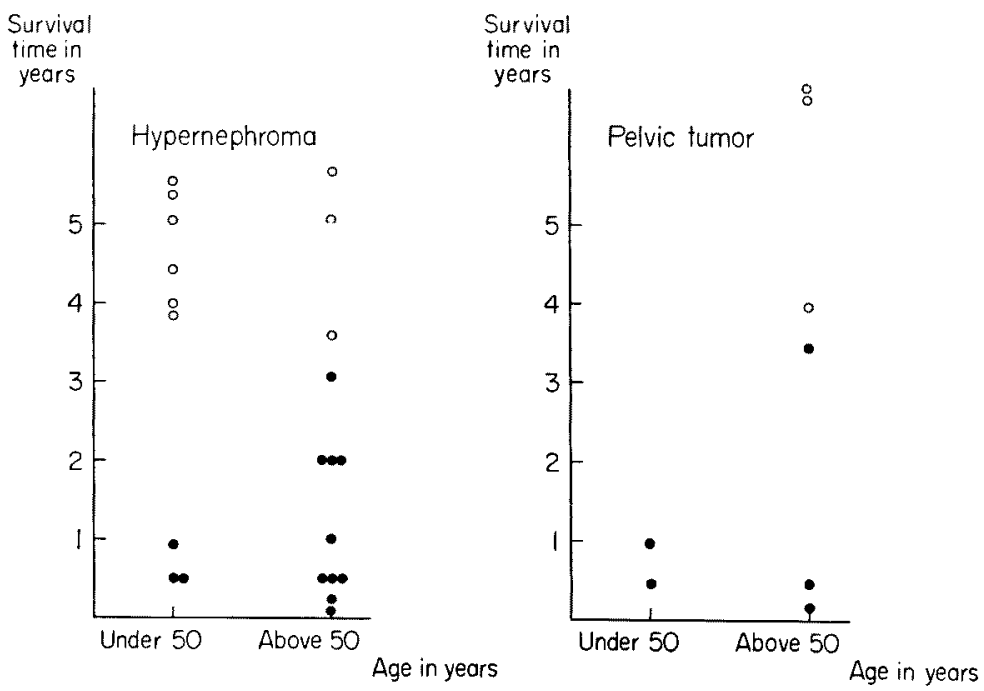

Fig. 1. Age at onset and survival time.
- Survival
- Death 
Follow-up period

\begin{tabular}{|c|c|c|c|c|c|}
\hline \multicolumn{3}{|l|}{ than } & \multirow{2}{*}{$\begin{array}{l}\text { More } \\
\text { than } \\
5 \text { yrs }\end{array}$} & \multirow{2}{*}{$\frac{\begin{array}{c}3 \text {-year } \\
\text { survival }\end{array}}{(\%)}$} & \multirow{2}{*}{$\begin{array}{c}\begin{array}{c}5 \text {-year } \\
\text { survival }\end{array} \\
\%)\end{array}$} \\
\hline $2 \mathrm{yrs}$ & 3 yTs & 5 yrs & & & \\
\hline 3 & 2 & $5(5)$ & $4(4)$ & $23(9) \quad 39$ & \\
\hline \multirow[t]{3}{*}{2} & 1 & & $4(4)$ & & $13(4) 30$ \\
\hline & & $3(1)$ & $2(2)$ & $9(3) \quad 33$ & \\
\hline & & 1 & $2(2)$ & & $6(2) 33$ \\
\hline
\end{tabular}

the number of patients still alive.

$3 / 9(33 \%)$ for pelvic tumor, while the 5-year survival rate was $4 / 13(30 \%)$ for hypernephroma and $2 / 6(33 \%)$ for pelvic tumor.

Age of onset. The age at the onset of the disease is listed in Table 2. It is obvious that the peak of frequency is found at 51 to 60 years for hypernephroma, and 61 to 70 years for pelvic tumor. Fig. 1 illustrates the relation between the age of onset and the survival time. In the hypernephroma group 6 of 10 cases under 50 years of age, but only 3 of 13 above that age are alive. Of the patients with pelvic tumor, 2 patients under 50 years of age died within a year, while 3 of those above 51 years of age are still alive.

Period from the onset to the first visit. The period from the onset of symptoms to the first visit is shown in Table 3. The average was 18 months for patients with hypernephroma and 11 months for those with pelvic tumor. The relation of this period to the survival time is presented in Fig. 2 . It can be seen that the

TABLE 3. Period from onset of disease to the first visit

\begin{tabular}{|c|c|c|c|c|c|c|c|c|c|c|}
\hline & \multicolumn{8}{|c|}{ Less than } & \multirow{2}{*}{$\begin{array}{l}\text { More } \\
\text { than } \\
10 \mathrm{yrs}\end{array}$} & \multirow{2}{*}{ Total } \\
\hline & $1 \mathrm{mo}$ & $2 \mathrm{mos}$ & $3 \mathrm{mos}$ & $6 \mathrm{mos}$ & $1 \mathrm{yr}$ & $2 \mathrm{yrs}$ & 5 yrs & $10 \mathrm{yrs}$ & & \\
\hline $\begin{array}{l}\text { Hyper- } \\
\text { nephroma }\end{array}$ & $3(1)$ & $3(2)$ & $2(1)$ & $4(1)$ & $4(3)$ & $4(1)$ & 1 & & 2 & $23(9)$ \\
\hline $\begin{array}{l}\text { Pelvic } \\
\text { tumor }\end{array}$ & 2 & & $1(1)$ & $3(2)$ & & 1 & 2 & & & $9(3)$ \\
\hline Total & $5(1)$ & $3(2)$ & $3(2)$ & $7(3)$ & $4(3)$ & $5(1)$ & 3 & & 2 & $32(12)$ \\
\hline
\end{tabular}

Figures in parentheses indicate the number of patients still alive, 

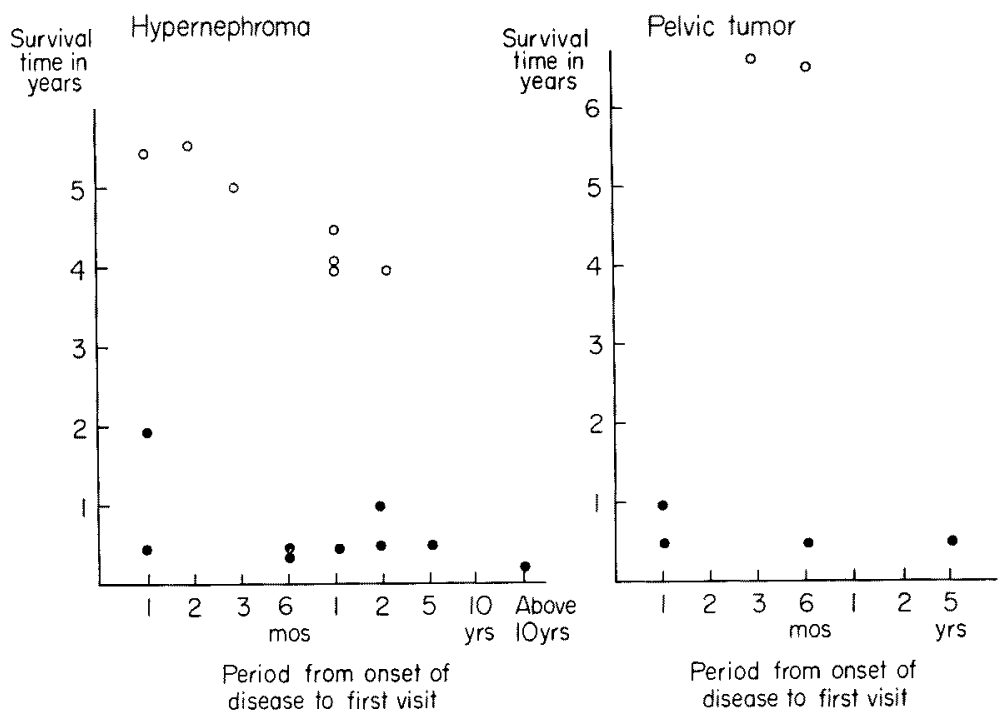

Fig. 2. Period from onset of disease to first visit and survival time.
- Survival
- Death

survival rate was higher for those who came for consultation within a year of the first symptoms.

Tumor size. The size of tumor detected at the first examination is given in Table 4. Although it is well known that the size of a renal tumor on palpation does not necessarily correspond to its actual size, the tumors were roughly classified into 3 groups according to their size on palpation in this table. Those referred to as 'large' were palpable over 4 finger-widths below the costal margin; those as 'moderate', 2 to 4 finger-widths; and those as 'small', under 2 finger-widths.

Fig. 3 illustrates the relation between the size of tumor and the survival time. It shows a distinct correlation between the two factors in patients with hypernephroma. None of the patients found to have a 'large' tumor at the first examination survived more than 3 years. Among those with a tumor of 'moderate' size, 4 are still alive but 2 others died within 6 months of the first examination. Of 4

TABLE 4. Size of renal tumor at the first visit

\begin{tabular}{|c|c|c|c|c|c|}
\hline & Large & Moderate & Small & $\begin{array}{c}\text { Not } \\
\text { palpable }\end{array}$ & Total \\
\hline Hypernephroma & 7 & $7(4)$ & $4(2)$ & $5(3)$ & $23(9)$ \\
\hline Pelvic tumor & 2 & 1 & $4(1)$ & $2(2)$ & $9(3)$ \\
\hline Total & 9 & $8(4)$ & $8(3)$ & $7(5)$ & $32(12)$ \\
\hline
\end{tabular}

Figures in parentheses indicate the number of patients still surviving. 

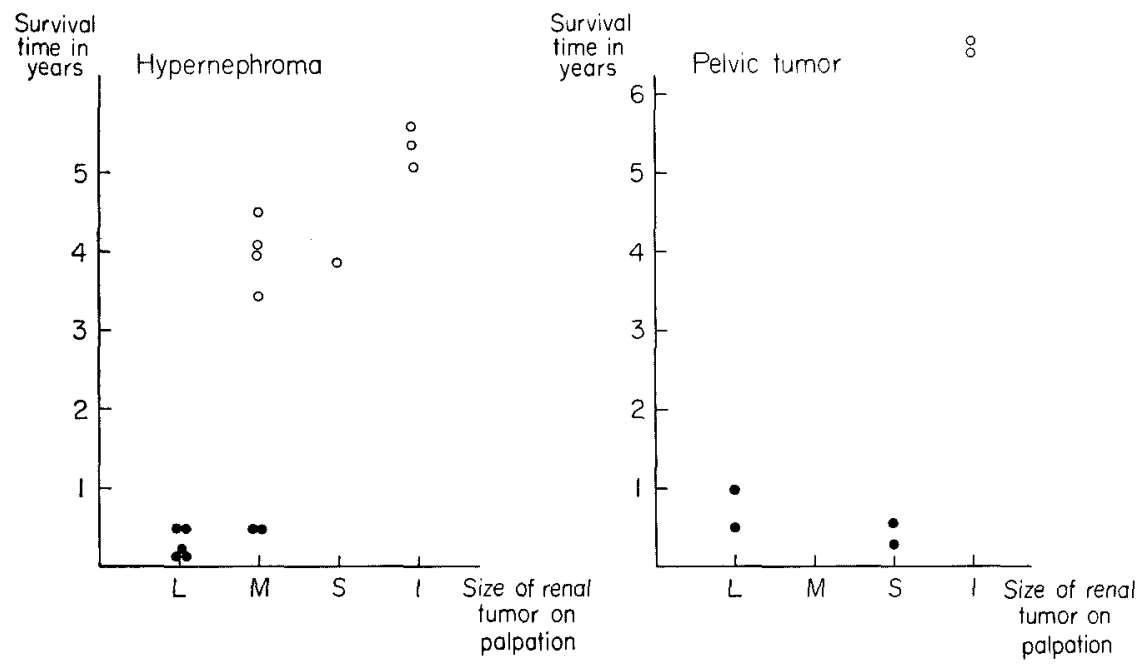

Fig. 3. Size of tumor at first visit and survival time.
L: Large
M: Moderate
S: Small
I: Impalpable
- Survival
- Death

cases with a 'small' tumor, there are 2 survivors, while 3 are still alive out of 5 cases where the tumor was impalpable at the first examination.

A similar and definite correlation is proved also in cases of pelvic tumor. All the patients with pelvic tumors of 'large' or 'moderate' size at the first examination had died at the time of the present study.

Findings at operation. Table 5 summarized the extent of tumor discovered at operation. The relation between the degree of tumor extension and the survival time is shown in Fig. 4. A distinct difference in the survival time between hypernephroma cases of lesions confined within the renal capsule and those with extracapsular tumor spread; that is, 6 out of 11 are surviving in the former, whereas only 3 out of 12 in the latter. Of 4 patients in whom daughter nodes were demonstrable in the renal substance or pelvis, 3 died within 6 months, and only one survived 5 years. In one case where infiltration had reached adjacent muscles, death occurred within 6 months. However, in another case the patient survived 3 years in spite of involvement of the liver capsule at the time of operation. On the other hand, all of 7 patients with tumor embolism of the renal vein died mostly within 6 months.

As for pelvic tumors, no difference in the survival time was noticeable between cases of intrarenal tumor and those of extracapsular extension; that is, 2 of the former 5 cases are still alive, and one of the latter 4 cases has survived more than 5 years.

Of 5 cases where the ureter was found to be invaded by the tumor, only one is alive. Both the afore-mentioned patient having muscular infiltration and the one 
TABLE 5.

\begin{tabular}{l|c|c|c|c|}
\hline & $\begin{array}{c}\text { Intra-capsular } \\
\text { infiltration }\end{array}$ & $\begin{array}{c}\text { Extra-capsular } \\
\text { infiltration }\end{array}$ & $\begin{array}{c}\text { Intrapelvic } \\
\text { infiltration }\end{array}$ & $\begin{array}{c}\text { Extra-pelvic } \\
\text { infiltration }\end{array}$ \\
\hline Hypernephroma & $11(6)$ & $\mathbf{1 2 ( 3 )}$ & & \\
\hline Pelvic tumor & $5(2)$ & $\mathbf{4}(1)$ & $2(1)$ & $7(2)$ \\
\hline Total & $16(8)$ & $16(4)$ & $2(1)$ & $7(2)$
\end{tabular}

Figures in parentheses indicate the number

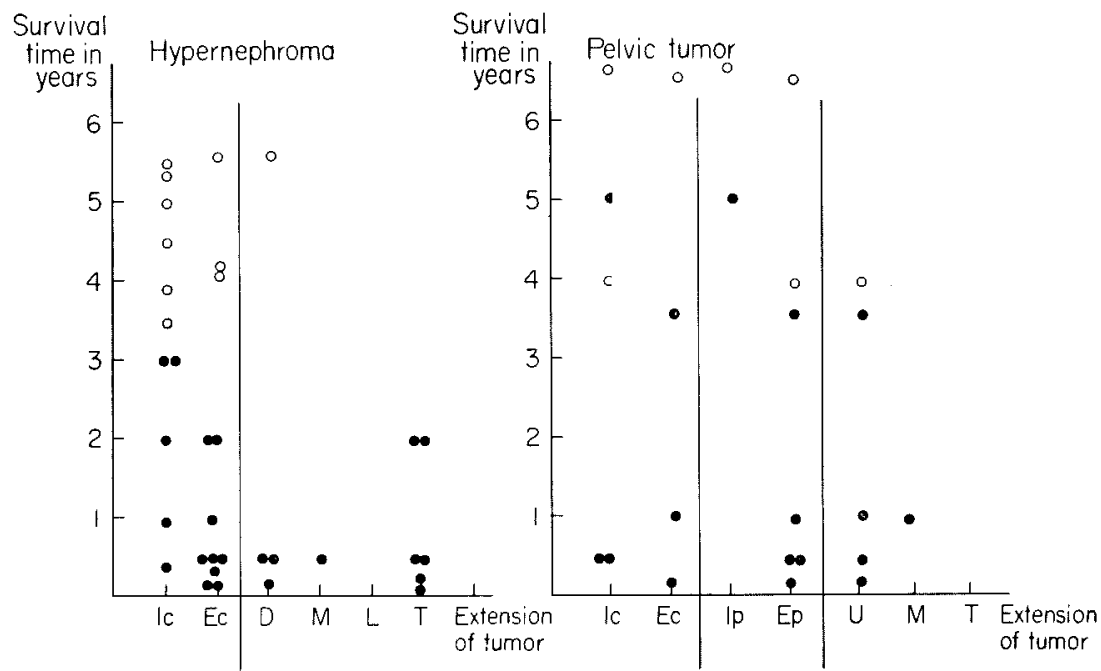

Fig. 4. Extent of tumor and survival time.

Ic: Intracapsular. Ec: Extracapsular. D: Daughter nodes present. M: Muscle involvement. L: Hepatic floor invaded. $\mathrm{T}$ : Tumor embolism of veins. Ip: Intrapelvic. Ep: Extrapelvic. U: Ureter involved.

o Survival - Death

with tumor embolism of the renal vein died.

Kidney weight. The weight of extirpated kidneys is given in Table 6. The kidneys harboring parenchymal neoplasm averaged $470 \mathrm{~g}$ in weight. Fig. 5 illustrates the relation between the weight of the extirpated kidneys and the survival time. It becomes apparent from the figure that 8 of the 9 survivors had a renal weight below the average. In 9 cases of pelvic tumor, on the other hand, the renal weight had an average of $270 \mathrm{~g}$ and 3 survivors showed values of renal weight smaller than the average.

Metastasis. As seen in Table 7, metastatic lesions of hypernephroma were demonstrable in 11 cases, in 3 of which tumor metastasis became manifest only after 
Extent of tumor

\begin{tabular}{c|c|c|c|c}
\hline $\begin{array}{c}\text { Invasion } \\
\text { of } \\
\text { ureter }\end{array}$ & $\begin{array}{c}\text { Daughter } \\
\text { nodes } \\
\text { formed }\end{array}$ & $\begin{array}{c}\text { Involvement } \\
\text { of } \\
\text { muscles }\end{array}$ & $\begin{array}{c}\text { Involvement } \\
\text { of } \\
\text { hepatic floor }\end{array}$ & $\begin{array}{c}\text { Venous } \\
\text { embolism }\end{array}$ \\
\hline $5(1)$ & $\mathbf{4}(1)$ & 1 & $\mathbf{1}(\mathbf{1})$ & 1 \\
\hline $5(1)$ & $\mathbf{4 ( 1 )}$ & 2 & 8
\end{tabular}

of patients still surviving.

TABLE 6. Weight of extirpated kidney

\begin{tabular}{l|c|c|c|c|c|c}
\hline & $\begin{array}{c}\text { Number } \\
\text { of cases }\end{array}$ & $\begin{array}{c}\text { Below } \\
200 \mathrm{~g}\end{array}$ & $\begin{array}{c}200 \mathrm{to} \\
500 \mathrm{~g}\end{array}$ & $\begin{array}{c}500 \mathrm{to} \\
1,000 \mathrm{~g}\end{array}$ & $\begin{array}{c}\text { Above } \\
1,000 \mathrm{~g}\end{array}$ & Average \\
\hline Hypernephroma & $23(9)$ & $3(2)$ & $12(6)$ & $7(1)$ & 1 & $470 \mathrm{~g}$ \\
\hline Pelvic tumor & $9(3)$ & 2 & $7(3)$ & & & $270 \mathrm{~g}$ \\
\hline & $32(12)$ & $5(2)$ & $19(9)$ & $7(1)$ & 1 &
\end{tabular}

Figures in parentheses indicate the number of patients still surviving.
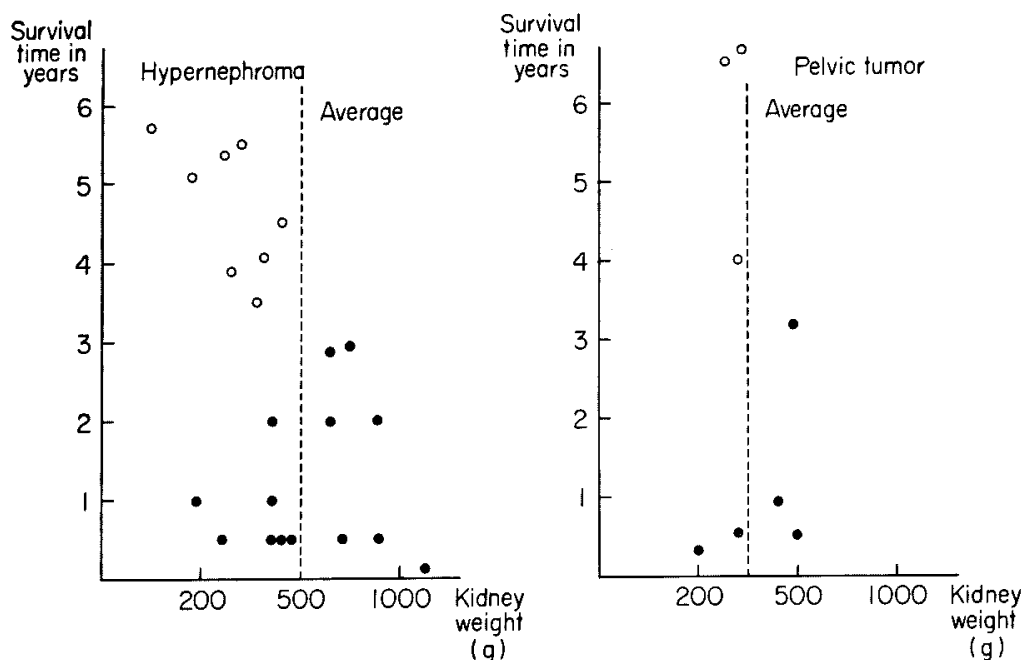

Fig. 5. Weight of excised kidney and survival time.

\section{- Survival - Death}

the operation. The tumor had metastasized mostly to the lungs. Of 8 cases where metastasis was found before surgery, 7 died within 2 years and the remaining one with solitary metastasis to the lungs has survived 3 and a half years. All three patients, in whom metastatic lesions were detected after discharge from the hospital, died within the following 2 years, 
TaBle 7. Metastases seen before

\begin{tabular}{c|c|c|c|c|}
\hline & $\begin{array}{c}\text { Number of } \\
\text { cases }\end{array}$ & $\begin{array}{c}\text { To more than 2 } \\
\text { organs }\end{array}$ & Skull & Lungs \\
\hline Hypernephroma & $11(3)$ & 3 & 1 & $10(2)$ \\
\hline Pelvic tumor & $4(1)$ & 1 & 3 \\
\hline & $15(4)$ & 4 & 1 & $13(2)$ \\
\hline
\end{tabular}

Figures in parentheses indicate the number of cases of
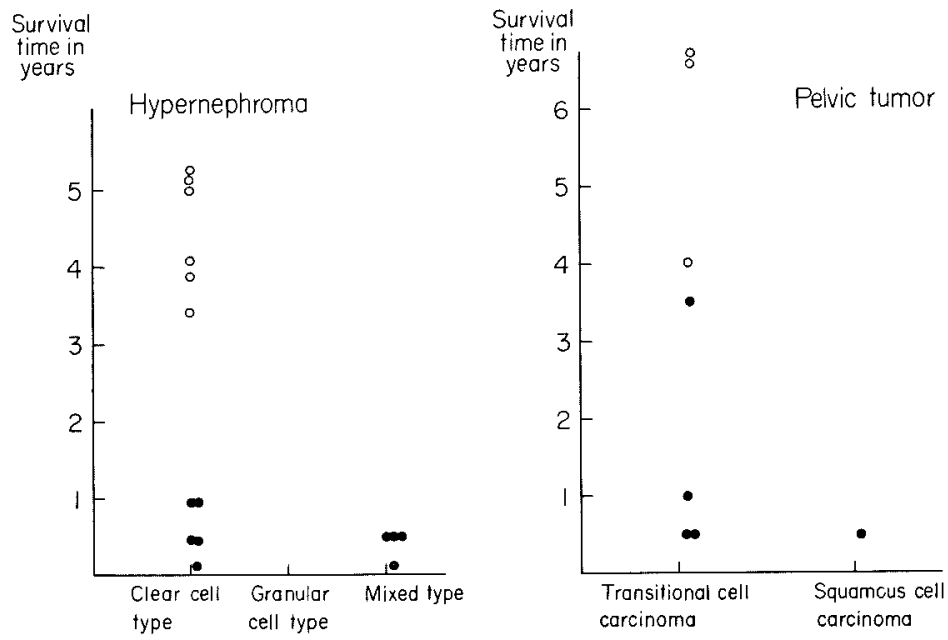

Fig. 6. Histological findings and survival time.

- Survival Death

Metastases of the pelvic tumor were seen in all of 4 cases, 3 preoperatively and 1 after discharge. These patients all died within 4 years.

Histological findings. In the cases of hypernephroma the tumors were histologically of clear cell type in 13 cases, of granular cell type in 1 and of mixed type in the other 9 . The relation between the histological findings and the survival time is illustrated in Fig. 6. It is evident that there is no substantial difference in the survival time among the 3 types. Of the 13 cases of clear-cell hypernephroma, 6 are still alive and the other 7 died within 2 years, while the one case of granularcell hypernephroma has survived 4 years and 5 months. Of the 9 cases of mixed type carcinoma, 2 are still alive and the others died in less than 3 years.

Out of 9 cases of pelvic tumors 8 had histologically transitional-cell carcinoma while in the other one the histological pattern was characterized by partial hyperkeratosis suggestive of squamous cell carcinoma. In the latter case the patient died within a year after nephrectomy (Fig. 6). 
operation or after discharge

\begin{tabular}{c|c|c|c|c}
\hline Vertebrae & Long bones & $\begin{array}{c}\text { Cervical } \\
\text { lymph nodes }\end{array}$ & $\begin{array}{c}\text { Greater } \\
\text { omentum }\end{array}$ & $\begin{array}{c}\text { Cancerous } \\
\text { peritonitis }\end{array}$ \\
\hline 1 & 1 & 1 & 1 & $(1)$ \\
\hline 1 & 1 & 1 & $(1)$ \\
\hline
\end{tabular}

metastasis detected after discharge from the hospital.

TaBle 8. Combined therapies

\begin{tabular}{l|c|c|c|c}
\hline & $\begin{array}{c}\text { Nephrectomy } \\
\text { only }\end{array}$ & $\begin{array}{c}\text { Nephrectomy } \\
\text { plus } \\
\text { chemotherapy }\end{array}$ & $\begin{array}{c}\text { Nephrectomy } \\
\text { plus } \\
\text { radiotherapy }\end{array}$ & $\begin{array}{c}\text { Nephrectomy } \\
\text { plus } \\
\text { chemotherapy } \\
\text { and radiotherapy }\end{array}$ \\
\hline Hypermephroma & $8(5)$ & $11(4)$ & 1 & 3 \\
\hline Pelvic tumor & $6(3)$ & 2 & 1 & 3 \\
\hline & $14(8)$ & $13(4)$ & 2 & \\
\hline
\end{tabular}

Figures in parentheses indicate the number of patients still alive.

Accessory therapy. As indicated in Table 8, chemotherapy (Mitomycin, Toyomycin), and radiotherapy by cobalt or $x$-ray were used in combination with surgical treatment. In all the cases of these combined therapies the disease had already considerably advanced at the time of treatments.
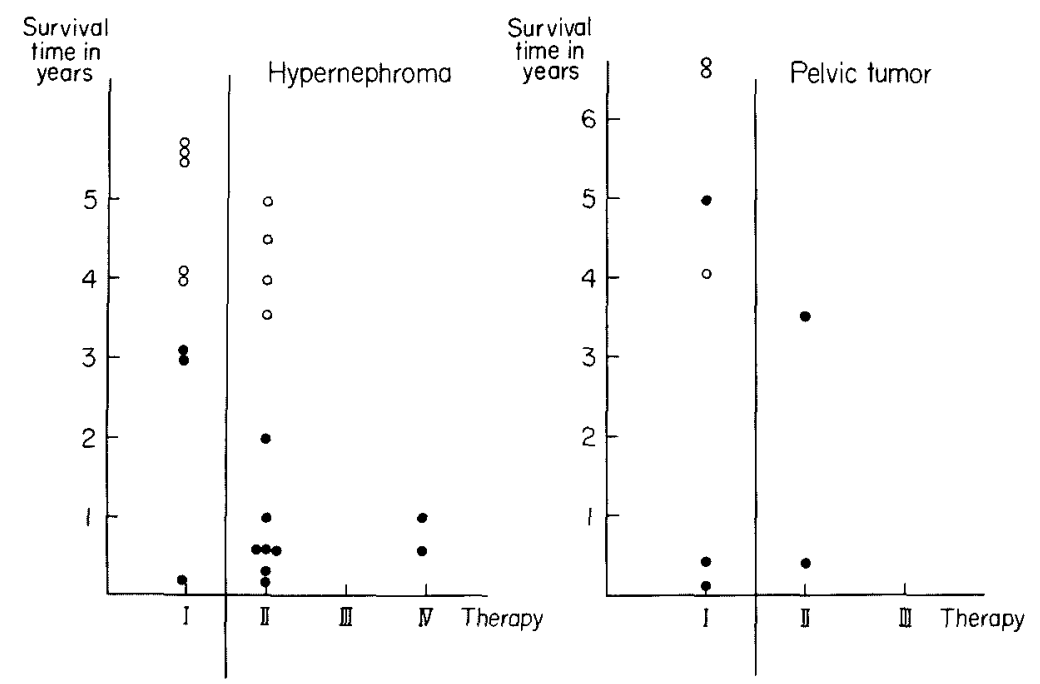

Fig. 7. Therapy and survival time.

I: Nephrectomy alone II: Nephrectomy+chemotherapy

III: Nephrectomy + radiotherapy IV: Combination of the three

- Survival Death 
TABLE 9.

\begin{tabular}{|c|c|c|c|c|c|}
\hline & $\begin{array}{c}\text { Case } \\
\text { No. }\end{array}$ & Age & $\begin{array}{l}\text { Period from } \\
\text { onset of } \\
\text { symptom to } \\
\text { first visit }\end{array}$ & Size of tumor & Venous pyelogram \\
\hline Hypernephroma & $\begin{array}{l}1 \\
2 \\
3 \\
4 \\
5 \\
6\end{array}$ & $\begin{array}{l}74 \\
66 \\
65 \\
65 \\
55 \\
70\end{array}$ & $\begin{array}{l}\text { Uncertain } \\
\text { Above } 10 \text { yrs } \\
6 \text { mos } \\
2 \text { yrs } \\
3 \text { mos } \\
5 \text { yrs }\end{array}$ & $\begin{array}{l}\text { Moderate } \\
\text { Large } \\
\text { Moderate } \\
\text { Large } \\
\text { Large } \\
\text { Large }\end{array}$ & $\begin{array}{l}\text { Complete filling } \\
\text { defect } \\
\text { Calyxes and pelvis } \\
\text { obliterated } \\
\text { Pelvis distorted, } \\
\text { calyxes obliterated } \\
\text { Complete filling } \\
\text { defect } \\
\text { " }\end{array}$ \\
\hline Pelvic tumor & $\begin{array}{l}7 \\
8\end{array}$ & $\begin{array}{l}61 \\
75\end{array}$ & $\begin{array}{c}2 \mathrm{yrs} \\
3 \mathrm{yrs} 6 \mathrm{mos}\end{array}$ & $\begin{array}{l}\text { Moderate } \\
\text { Indefinite }\end{array}$ & Calyxes obliterated \\
\hline
\end{tabular}

Fig. 7 presents the relation between the combined therapy and the survival time. Of the patients with hypernephroma, 4 of 11 who were treated with chemotherapeutic agents are still alive; one died in 2 years during concurrent radiotherapy; 3 who received both chemotherapy and radiotherapy in addition to nephrectomy died within 2 years. As for our pelvic tumor patients, neither 2 receiving chemotherapy nor one given radiotherapy is alive.

\section{Results of non-nephrectomy cases}

As indicated in Table 9 , the cases where nephrectomy was not feasible included 6 of hypernephroma and 2 of pelvic tumor. The outcome of the patients were fatal.

\section{Discussion}

The prognosis in renal neoplasms has been generally considered to depend largely upon the following three major factors; 1) the degree of topological extension of the lesion; 2) the degree of malignancy from the viewpoint of the histological pattern, and 3) therapeutic measures.

Flocks and Kadesky ${ }^{1}$ divided renal tumors into four stages according to the extent of the lesion as follows:

1) Limitation by the renal capsule,

2) Invasion of the pedicle and/or the perinephric fat,

3) Involvement of regional lymph nodes, and

4) Distant metastases demonstrable.

Although the extent of intrarenal tumor spread and involvement of the renal vein is not taken into account in this classification, they stated that there 
Non-nephrectomy cases

\begin{tabular}{|c|c|c|c|c|}
\hline $\begin{array}{l}\text { Findings at } \\
\text { operation }\end{array}$ & Metastasis & Histology & Therapy & Outcome \\
\hline $\begin{array}{l}\text { Extracapsular } \\
\text { infiltration } \\
n\end{array}$ & $\begin{array}{l}\text { Chest } \\
\text { None }\end{array}$ & $\begin{array}{c}\text { Clear-cell } \\
\end{array}$ & $\begin{array}{c}\text { Exploratory } \\
\text { laparotomy } \\
\text { " }\end{array}$ & $\begin{array}{l}\text { Death after } 6 \mathrm{mos} \\
\text { Survived } 5 \mathrm{yrs} \& 1 \mathrm{mo}\end{array}$ \\
\hline $\begin{array}{l}\text { Not operated } \\
\text { upon }\end{array}$ & $"$ & - & - & Death after 6 mos \\
\hline$n$ & Chest & $\begin{array}{l}\text { Mixed type } \\
\text { (biopsy) }\end{array}$ & Chemotherapy & Death after $3 \mathrm{mos}$ \\
\hline$"$ & $\begin{array}{l}\text { Chest \& } \\
\text { hepatic floor } \\
\text { None }\end{array}$ & - & " & $\begin{array}{l}\text { Death after } 1 \mathrm{mo} \\
\text { Death after } 1 \mathrm{yr}\end{array}$ \\
\hline $\begin{array}{l}\text { Extracapsular } \\
\text { infiltration } \\
\text { Not operated } \\
\text { upon }\end{array}$ & $"$ & - & $\begin{array}{c}\text { Exploratory } \\
\text { laparotomy } \\
-\end{array}$ & $\begin{array}{l}\text { Death after } 1 \mathrm{yr} \\
\text { Death after } 4 \text { yrs } \\
\quad \& 3 \mathrm{mos}\end{array}$ \\
\hline
\end{tabular}

was an apparent difference in prognosis between cases of stage 1 and those of stages 2 to 4 .

Petkovic ${ }^{2}$ also proposed the following 4 stages in the spread of renal tumors.

a) Intracapsular; the pseudo-capsule of the tumor is intact.

b) Intrarenal, extracapsular; the pseudo-capsule is broken or absent. In stages a) and b) neither veins nor lymphatics are invaded.

c) Periorganic; there is no pseudo-capsule or only a trace of it, and the tumor has not only given rise to intrarenal metastasis but also spread into and adhered to the perirenal tissue. Veins and adjacent lymphatics are invaded.

d) Systemic involvement; distant metastases are demonstrable, though local findings are similar to those at stage $\mathrm{c}$ ).

He reported that a distinct correlation was noticeable between these stages and the predictable development of the disease.

In our grading of the development of renal neoplasms, 'intracapsular invasion' corresponds to Flocks and Kadesky's stage 1) and Petkovic's stage a), and our 'extracapsular invasion', to their stage 2) and stage b), and some differences in prognosis are noted between Flocks and Kadesky's and Petkovic's classifications.

According to Petkovic's classification, tumor embolism is to be included in c). Concerning the difference in prognosis between patients with and without tumor embolism, McDonald and Priestley ${ }^{3}$ reported that the 5-year survival rate in the former was $29 \%$, while that in the latter $55.4 \%$. Similar results were reported by Riches ${ }^{4}$ and Arner et al. ${ }^{5}$ Our own result also indicated that none of the patients with tumor embolism of the renal veins survived more than 3 years.

As for pelvic tumors, Riches ${ }^{4}$ stated that prognosis in cases of the papillary tumor of the renal pelvis was somewhat more favorable for patients with the 
lesion confined in the urinary tract than for those with the lesion spreading outside the tract. In our present study, however, no definite difference was noticeable, probably because of the small number of our examined cases.

As for the relation of the weight or size of the tumor to prognosis, Bixler et al. ${ }^{6}$ divided the patients with parenchymal tumor of the kidney into 2 groups according to the weight of the affected kidney, below $500 \mathrm{~g}$ and 500 to $1,000 \mathrm{~g}$. They reported that the fatality in the first year following nephrectomy was $20 \%$ for the former group, whereas it was as high as $40 \%$ for the latter. Arner et al. ${ }^{5}$ also described that the 5-year survival rate in a group of patients with parenchymal tumor of less than $7 \mathrm{~cm}$ in diameter was $69.4 \%$, while that of 7 to $15 \mathrm{~cm}$ in diameter was $39.6 \%$. Besides, there have been a number of similar reports on this problem. So far as our present study is concerned, the weight of extirpated kidneys containing parenchymal neoplasm averaged $470 \mathrm{~g}$, and that of the kidneys bearing pelvic tumor averaged $279 \mathrm{~g}$. And the difference in prognosis was quite evident according to whether the weight of extirpated kidney was above or below the average.

The presence of distant metastases makes of course the prognosis worse. Flocks and Kadesky ${ }^{1}$ reported that the 5 and 10 -year survival rates of the patients with metastases of hypernephroma were $3.5 \%$ and $1.3 \%$, respectively. Our results revealed that only one of 11 cases of hypernephroma with demonstrable metastases survived three and a half years, while none of the patients with pelvic tumor with systemic involvement survived more than 5 years.

The correlation between the histological findings and prognosis has been intensely debated. Hypernephroma is usually divided into the following 3 types from the histological point of view; clear-cell, granular-cell, and mixed types. Riches $^{4}$ stressed the difference in prognosis among these 3 types and not a few authors have agreed with him. On the other hand, there are some reports stating that histological features, whether of clear-cell or of granular-cell, have no distinct bearing upon the prognosis. For instance, $\mathrm{Muto}^{7}$ is of the opinion that clinical symptoms are quite the same in adult patients with hypernephroma regardless of whether the tumor is histologically of clear-cell or granular-cell type and he has pointed out that hypernephroma is rarely composed of clear cells only, and usually contains more or less granular cell elements too, and further that these two types of tumor cell are entirely the same in their origin, differing from each other only in appearance at different stages of development. In our present study, histological diagnosis could be established in a total of 26 cases including those of exploratory laparotomy, and no significant difference in prognosis was notable between the two histological patterns. Only one of the patients having granular-cell carcinoma survived 4 years and 5 months after nephrectomy.

On the other hand, pelvic tumors may be classified histologically into transitional cell carcinoma and squamous cell carcinoma, and an apparent difference in prognosis is known to exist between the two types. Riches ${ }^{4}$ and Higgins ${ }^{8}$ described that they had never experienced a case of squamous cell carcinoma, in which the patient had survived more than 5 years. One patient of our series with pelvic 
tumor composed partially of squamous cell elements died in less than a year.

As for radiotherapy, Royce and Tormey ${ }^{9}$ stated that in renal tumors even large doses of $\mathrm{x}$-ray and ${ }^{60} \mathrm{Co}$ brought about no favorable therapeutic response but rather untoward side effects, expressing therefore a pessimistic view on the effect of such treatments. On the contrary, Riches ${ }^{10}$ and Bratherton ${ }^{11}$ found radiotherapy to be of benefit. Bratherton reported that the 3-, 5- and 10-year survival rates in a group of patients treated by nephrectomy alone averaged $38 \%, 29 \%$ and $27 \%$ respectively, while those of the patients who received both nephrectomy and x-ray radiation were generally higher and $44 \%, 43 \%$ and $33 \%$, respectively. So far as our present study is concerned, the prognosis was not necessarily improved by concurrent radiotherapy. This is probably because our cases received radiotherapy at an advanced stage where the recurrence was inevitable, and so any negative conclusion concerning the effectiveness of $x$-ray radiation cannot be drawn out of our results.

The results of chemotherapy hitherto reported are also rather disappointing. Woodruff et al., ${ }^{12}$ for instance, could observe a therapeutic response in only 30 out of 270 cases in which concomitant use of anticancer agents had been made. In our present series, the combined use of chemotherapeutic agents resulted adversely in the worsening of prognosis. This may be presumably due to the fact that chemotherapy was carried out exclusively in those cases where the disease had already much advanced.

\section{Acknowledgment}

Grateful acknowledgments are due to Prof. S. Shishito for his guidance and review of the manuscript.

\section{References}

1) Flocks, R.H. \& Kadesky, M.C. Malignant neoplasma of the kidney, analysis of 353 patients followed five years or more. J. Urol., 1958, 79, 196-201.

2) Petkovic, S.D. An anatomical classification of renal tumors in the adult as basis for prognosis. J. Urol., 1959, 81, 618-621.

3) McDonald, J.P. \& Priestley, J.T. Malignant tumors of the kidney: surgical and prognostic significance of tumor thrombosis of the renal vein. Surg. Gynec. Obstet., 1943, 77, 295-306.

4) Riches, E. Tumor of the Kidney and Ureter. Monographs on Neoplastic Disease $V$. Livingston, Edinburgh, 1964, pp. 1-415.

5) Arner, O., Blanck, C. \& von Schreeb, T. Renal adenocarcinoma, morphologygrading of malignancy-prognosis: a study of 197 cases. Acta chir. scand., Suppl., $1965,346$.

6) Bixler, L.C., Stenstrom, K.W. \& Creevy, C.D. Malignant tumors of the kidney: review of 177 cases. Radiology, 1944, 42, 329-335.

7) Muto, M. Tumors of the Kidney (Jap.), Igakushoin, Tokyo, 1959.

8) Higgins, C.C. Tumors of renal pelvis. Ann. Surg., 1953, 137, 195-204.

9) Royce, R.K. \& Tormey, A.R., Jr. Malignant tumors of the renal parenchyma in adults. J. Urol., 1955, 74, 23-35.

10) Riches, $\mathrm{E}$. The place of radiotherapy in the management of parenchymal carcinoma of the kidney. J. Urol., 1966, 95, 313-317. 
11) Bratherton, D.G. The place of radiotherapy in the treatment of hypernephroma. Brit. J. Radiol., 1964, 37, 141-146.

12) Woodruff, M.W., Wagle, D., Gailanai, S.D. \& Jones, R., Jr. The current status of chemotherapy for advanced renal carcinoma. J. Urol., 1967, 97, 611-618. 